\title{
Different mechanisms of cis-9,trans-11- and trans-10,cis-12- conjugated linoleic acid affecting lipid metabolism in 3T3-L1 cells
}

\author{
Jia-jie Zhai ${ }^{\mathrm{a}, \mathrm{c}}$, Zhao-liang Liu' ${ }^{\mathrm{b}}$, Jie-mei Lic, Jian-Ping Chen ${ }^{\mathrm{d}}$, Lin Jiang ${ }^{\mathrm{c}}$, Dong-mei Wang ${ }^{\mathrm{c}}$, Jin Yuan ${ }^{\mathrm{a}}$, \\ Jian-Gang Shen ${ }^{\mathrm{d}}$, De-Po Yang, ${ }^{\mathrm{c}, *}$, Jia-Qi Chen ${ }^{\mathrm{a}, *}$ \\ anstitute of Ophthalmology and Visual Sciences of Guangdong Province, Guangzhou 510080, China \\ ${ }^{\mathrm{b}}$ Chemical Industry and Ecology Institute, North University of China \\ 'Laboratory of Pharmacognosy and Natural Medicinal Chemistry, School of Pharmaceutical Sciences, Sun Yat-sen University, Guangzhou 510080, China \\ ${ }^{\mathrm{d}}$ School of Chinese Medicine, University of Hong Kong SAR
}

Received 10 November 2008; received in revised form 28 February 2009; accepted 21 September 2009

\begin{abstract}
Conjugated linoleic acid (CLA) has been shown to reduce body fat mass in various experimental animals. It is valuable to identify its influence on enzymes involved in energy expenditure, apoptosis, fatty acid oxidation and lipolysis. We investigated isomer-specific effects of high dose, long treatment of CLA (75.4 $\mu \mathrm{mol} / \mathrm{L}, 8$ days) on protein and gene expression of these enzymes in cultured 3T3-L1 cells. Proteomics identified significant up- or down-regulation of 52 proteins by either CLA isomer. Protein and gene expression of uncoupling protein (UCP) 1, UCP3, perilipin and peroxisome proliferator-activated receptor (PPAR) $\alpha$ increased whereas UCP2 reduced for both CLA isomers. And eight-day treatment of trans-10,cis-12 CLA, but not cis-9,trans-11 CLA, significantly up-regulated protein and mRNA levels of PKA $(P<.05), \mathrm{CPT}-1$ and TNF- $\alpha(P<.01)$. Compared to protein expression, both isomers did not significantly influence the mRNA expression of HSL, ATGL, ACO and leptin. In conclusion, high-dose, long treatment of cis-9,trans-11 CLA did not promote apoptosis, fatty acid oxidation and lipolysis in adipocytes, but may induce an increase in energy expenditure. trans-10,cis-12 CLA exhibited greater influence on lipid metabolism, stimulated adipocyte energy expenditure, apoptosis and fatty acid oxidation, but its effect on lipolysis was not obvious.
\end{abstract}

(c) 2010 Elsevier Inc. All rights reserved.

Keywords: Conjugated linoleic acid; 3T3-L1; Lipid metabolism

\section{Introduction}

Conjugated linoleic acid (CLA) [1] refers to a mixture of positional and geometric isomers of conjugated octadecadienoic acids. CLA is effective [2] as anticarcinogenic, antidiabetic and antilipogenic agents in animal models [3,4]. CLA used in most feeding studies usually contained two major isomers: cis-9,trans11 and trans-10,cis-12 CLA, while concentrations of other isomers are much lesser. Dietary supplementation of CLA has been shown to reduce body fat mass in various experimental animal experiments [5-8] and human subjects [1,9], However, a recent study showed that CLA supplementation had no significant effect on body composition or energy expenditure in adult women, which contrasts with previous findings [10]. In addition cis-9,trans-11 CLA has different effects on lipid metabolism compared to trans10,cis-12 CLA. Comparative studies investigating the effects of these two isomers found out that trans-10,cis-12 CLA is effective in

\footnotetext{
* Corresponding author.

E-mail addresses: daphniezhai@hotmail.com (D.-P. Yang), daphnie1983@163.com (J.-Q. Chen).
}

reducing lipid accumulation of adipocytes, but not cis-9,trans-11 CLA [11-13].

The mechanisms of the CLA's lipid-lowering effects $s$ are considered to be related to modulate the expressions of protein and gene relevant to energy expenditure, apoptosis, fatty acid oxidation, lipolysis, differentiation and lipogenesis [6]. peroxisome proliferatoractivated receptor (PPAR) $\gamma$ is highly expressed in fat tissues and it has been shown to stimulate lipogenesis and adipose differentiation [14]. Reduced PPAR $\gamma$ plays a role in down-regulating the lipogenic enzymes, thus leading to reduced lipid accumulation. Several studies have demonstrated that chronic treatment of trans-10,cis-12 CLA decreases mRNA expression of PPAR $\gamma[13,15,16]$, thus the antilipogenic effect of CLA was not investigated in this study.

Most studies on specific effects of CLA isomers have been conducted in cultured 3T3-L1 cells. He et al. [17] concluded that the effects of CLA on fatty acid accumulation of 3T3-L1 cells is dependent on the isomer type, treatment period, and dose. However, present in vitro studies are usually conducted in short treatment period and low dose $[18,19]$. The purpose of this study was to examine the effect of high-dose, long treatment period of two major CLA isomers on the expression of genes relevant to energy expenditure, apoptosis, fatty 
acid oxidation and lipolysis. Also, the proteins that are up- or downregulated by either the cis-9,trans-11 isomer of CLA or the trans-10, cis-12 of CLA were identified by proteomics in the present study.

\section{Materials and methods}

\subsection{Chemicals and reagents}

All reagents were purchased from Sigma (St. Louis, MO, USA) and Merck (São Paulo, SP, Brazil). MilliQ water (Millipore, Bedford, MA, USA) was used for all solutions.

\subsection{Experimental design and cell culture}

The 3T3-L1 preadipocytes were cultured as described by Frost and Lane [20]. Briefly, the cells were grown in Dulbecco's modified Eagle's medium containing 10\% fetal bovine serum in a humidified $5 \% \mathrm{CO}_{2}$ atmosphere at $37^{\circ} \mathrm{C}$ for proliferation until confluence was attained. To induce differentiation, all the media including the control and the CLA treatments were supplemented with $0.1 \mu \mathrm{mol} / \mathrm{L}$ dexamethasone, $1 \mathrm{mmol} /$ $\mathrm{L}$ methyl-isobutylxanthine, and $0.1 \mu \mathrm{mol} / \mathrm{L}$ insulin at 2 days postconfluence. The time of addition of differentiation medium was designated as 0 day. Stock solutions of 21.1 mg CLA per milliliter of dimethyl sulfoxide (DMSO) were diluted to obtain final concentration $75.4 \mu \mathrm{mol} / \mathrm{L}(21.1 \mathrm{mg} / \mathrm{L})$ in culture medium. The final concentration of DMSO in culture medium was $0.1 \%$. Cultures were continuously (from Day 2 to Day 8 ) treated with $75.4 \mu \mathrm{M}$ of cis-9,trans-11 CLA or trans-10,cis-12 CLA in differentiation medium. The effects of two CLA isomers were compared with the vehicle control (DMSO only). Each treatment was replicated 6 times.

\subsection{Sample solubilization and protein concentration determination}

3T3-L1 cells were collected by centrifugation at $1400 \times \mathrm{g}$ for $5 \mathrm{~min}$ at $4^{\circ} \mathrm{C}$, and washed twice with phosphate-buffered saline (PBS) (0.01 M phosphate $0.145 \mathrm{M}$ $\mathrm{NaCl}$ ), $\mathrm{pH}$ 7.2. Then, they were lysed by 10 cycles of freezing and thawing in hypotonic PBS buffer $\left(13.6 \mathrm{mM} \mathrm{NaCl}, 0.27 \mathrm{mM} \mathrm{KCl}, 0.4 \mathrm{mM} \mathrm{Na} \mathrm{HPO}_{4}, 0.15 \mathrm{mM}\right.$ $\mathrm{KH}_{2} \mathrm{PO}_{4}$ ) containing a cocktail of protease inhibitors (Protease Arrest Geno Technology) [21,22]. The lysate was centrifuged at $14,000 \times \mathrm{g}$ for $15 \mathrm{~min}$ at $4^{\circ} \mathrm{C}$ to remove insoluble material and the soluble proteins in the resulting supernatant were precipitated with $10 \%(\mathrm{v} / \mathrm{v})$ TCA and washed with cold acetone under the same conditions. Finally, the pellet was resuspended in isoelectrical focusing (IEF) buffer [9 M urea, 4\% 3-[(3-cholamidopropyl)-dimethylamminio]-1-propane sulfonate (CHAPS), $40 \mathrm{mM}$ dithiothreitol (DTT) and 2\% Pharmalyte 3-10]. Resuspension was allowed to proceed for $1 \mathrm{~h}$ at room temperature. Protein concentration was determined using the 2D Quant Kit (GE Healthcare). Extracts were stored as singleuse samples of $500 \mu \mathrm{g}$ at $-80^{\circ} \mathrm{C}$ until analysis.

\subsection{Two-dimensional electrophoresis}

Electrophoresis conditions were used in the experiments as previously described [22]. Briefly, $500 \mu \mathrm{g}$ of protein was diluted to a final volume of $350 \mu \mathrm{L}$ in rehydration solution ( $9 \mathrm{M}$ urea, $2 \%$ CHAPS, $40 \mathrm{mM}$ DTT, $0.5 \%$ immobilized pH gradient [IPG] buffer $\mathrm{pH} 3-10$, trace bromophenol blue) and applied to the IPGstrip (18 cm, pH 3-10 nonlinear; Amersham Biosciences) by in-gel rehydration. All isoelectric focusing took place on an IPGphor system (Amersham Biosciences) using parameters described previously [22].After reduction and alkylation in the equilibration buffer [6 $\mathrm{M}$ urea, $2 \%$ sodium dodecyl sulfate (SDS), 300 mM Tris-HCl buffer $\mathrm{pH} 8.8,20 \%$ Glycerol], IPG strips (18 cm, pH3-10 nonlinear; Amersham Biosciences) were directly transferred to the second dimension gel. Proteins were separated on $12.5 \%$ SDS-polyacrylamide gel electrophoresis gels using an Ettan Daltsix large vertical system (Amersham Biosciences) and standard Tris/glycine/SDS buffer until the tracking dye left the gel.

\subsection{Protein visualization and image analysis}

Gels were stained with colloidal Coomassie Brilliant Blue G-250 following procedures described elsewhere [23], and documented using an ImageScanner II densitometer (Amersham Biosciences). Image analysis was performed using ImageMaster 2D Platinum software (Amersham Biosciences). Three independent cell suspensions for each sample were compared. To determine experimental $\mathrm{pI}$ and $\mathrm{Mr}$ coordinates for each single spot, 2DE gels were calibrated using a select set of reliable identification landmarks distributed throughout the entire gel.

\subsection{Protein digestion, peptide extraction and mass spectrometric analysis}

Protein spots were manually excised and treated for digestion as previously described [21,22]. Mass spectra were acquired on a 4700 Proteomics Analyzer mass spectrometer (MALDI-TOF/TOF) operating in delayed reflector mode with an accelerated voltage of $20 \mathrm{kV}$. MS/MS analysis was performed by precursor ion fragmentation of the five more intense peptides in the presence of $\mathrm{N} 2$ as collision induced dissociation (CID) gas at a collision cell pressure of $2.8 \times 10^{-6}$ Torr. The mass spectrometer was calibrated using the Sequazyme Standard kit (Applied Biosystem).

\subsection{Database search}

A combined search using the MS and MS/MS data against the National Center for Biotechnology non-redundant (NCBInr) database was performed by using the GPS Explorer Protein Analysis Software (Applied Biosystems) and Mascot database search engine. Mascot search parameters were: tryptic peptides with 1 missed cleavage allowed; no taxonomic restrictions; fixed modifications: carbamidomethylation of Cys residues; variable modifications: Met-oxidation, $\mathrm{N}$-terminal acetylation; mass accuracy within 100 ppm in MS and 0.5 Da for CID data. A global MASCOT score greater than 50 was considered significant $(P<.05)$. In addition, a hit was positive when a combination of the number of matching peptides (N5) in MS mode and peptides identified by MS/ MS $\left(\mathrm{N}_{2}\right)$ was found. Finally, proteins automatically identified were confirmed by manual sequencing of at least one matching peptide. Biological processes of identified proteins were assigned according to gene ontology annotations available at The Institute for Genomic Research Trichomonas vaginalis genome project database (http://www.tigr.org/tdb/e2k1/tva1/GeneNameSearch.shtml).

\subsection{RNA isolation and $q R T-P C R$}

After eight days of treatment, culture medium was removed, total RNA was isolated by using the RNeasy kit (Qiagen, Valencia, CA, USA). DNA contamination was eliminated by on-column DNase treatment (RNase-Free DNase Set; Qiagen). Total RNA concentration was determined spectrophotometrically at 260 and $280 \mathrm{~nm}$ (Eppendorf, Hamburg, Germany). The ratio of light absorbance at $260 \mathrm{~nm}$ to that at $280 \mathrm{~nm}$ was between 1.8 and 2.1 for all samples. Total RNA were subjected to cDNA synthesis using ReverTra Ace Kit (Toyobo, Osaka, Japan).

Quantitative real-time reverse transcriptase PCR (qRT-PCR) assays were developed for genes of interest (Table 1), and each sample was analyzed with $\beta$ actin as the internal control. Specific sense and antisense primers used to amplify cDNA were purchased from Shanghai Shenergy Biocolor Bioscience \& Technology Company. The final PCR reaction volume of $50 \mu \mathrm{l}$ contained $25 \mu \mathrm{l}$ SYBR Green PCR Master Mix (real-time PCR Master Mix; Toyobo, Osaka, Japan), $1 \mu$ cDNA template, 1 $\mu \mathrm{l}$ primer mixture and $23 \mu \mathrm{l}$ water. Thermal cycling was carried out with a $5 \mathrm{~min}$ denaturation step at $94^{\circ} \mathrm{C}$, followed by 40 two-step cycles: $30 \mathrm{~s}$ at $94^{\circ} \mathrm{C}, 30 \mathrm{~s}$ at $60^{\circ} \mathrm{C}$ and $30 \mathrm{~s}$ at $72^{\circ} \mathrm{C}$. Amplification data were collected by the ABI PRISM 7900 and analyzed by the Sequence Detection System 2.0 software (Applied Biosystems, Foster City, CA, USA).

Table 1

Primers for qRT-PCR of mRNAs

\begin{tabular}{|c|c|c|c|}
\hline Gene & Forward primer $\left(5^{\prime}-3^{\prime}\right)$ & Reverse primer $\left(5^{\prime}-3^{\prime}\right)$ & Accession No. \\
\hline$\beta$-Actin & TCCATCATGAAGTGTGACGT & GAGCAATGATCTTGATCTTCAT & M12481 \\
\hline $\operatorname{PPAR} \alpha$ & CCTFAAAGATTCGGAAACTGC & GGGTTGTTGCTGGTCTTTCC & NM_011144 \\
\hline HSL & TCGGGGAGCACTACAAACG & CACGCAACTCTGGGTCTATGG & U08188 \\
\hline PKA & ATGGACAGAAGATCGTGGTGC & GCAGCCCGAGGACGATT & NM_021880 \\
\hline Leptin & TCCAGGATGACACCAAAACC & CTCAGAATGGGGTGAAGCC & NM_008493 \\
\hline CPT & TATCGCCACCTGCTGAACC & TTGAAGGTGACGAAGGTGGT & AF320000 \\
\hline UCP1 & GCTACACGGGGACCTACAATG & CGTCATCTGCCAGTATTTTGTT & NM_009463 \\
\hline UCP2 & GGTCGGAGATACCAGAGCAC & TGAGGTTGGCTTTCAGGAGA & NM_011671 \\
\hline UCP3 & ATGAGTTTTGCCTCCATTCG & CCAGTTCCCAGGCGTATCA & NM_009464 \\
\hline Perilipin & CATGTCCCTATCCGATGCC & TCGGTTTTGTCGTCCAGG & ВС096685 \\
\hline ACO & GCCTTTGTTGTCCCTATCCG & TACATACGTGCCGTCAGGC & NM_015729 \\
\hline TNF- $\alpha$ & TTCTCATTCCTGCTTGTGGC & GGCTACAGGCTTGTCACTCG & NM_013693 \\
\hline ATGL & GGTGCCAACATTATTGAGGTG & AAACACGAGTCAGGGAGATGC & AY894805 \\
\hline
\end{tabular}


Results are presented as least squares mean \pm S.E.M. Data were analyzed using pairwise comparisons of mean values with Fisher's least significant difference test in SAS. Values are expressed relative to the control. Differences were considered significant at $P<.05$.

\section{Results}

\section{1. $2 D E$ and image analysis}

Representative 2DE gel images of Coomassie G-stained soluble proteins from three cell suspensions are shown in Fig. 1. Detection of spots and comparison of the protein expression was carried out using the ImageMaster 2D Platinum software. About 700 spots were detected in the blank (Fig. 1A), cis-9,trans-11 CLA treatment (Fig. 1B) and trans-10,cis-12 CLA treatment gels (Fig. 1C), corresponding to $1 \%$ of the theoretical proteome. Proteins within a molecular mass range of approximately $10-100 \mathrm{kDa}$ were detected in the $\mathrm{pH} 3-10$ gels. Image analyses were performed by comparing at least three representative gels that were obtained from three different cell suspensions for each isolate. The 2DE protein spot profiles obtained from these separate protein preparations were highly reproducible in terms of both total number of protein spots and their relative positions and intensities. Automatic comparison of matched gels revealed differences between the protein profiles of the isolates. The pixel volume of each spot provided the basis for comparison of protein expression between cis-9,trans-11 CLA treatment and trans10,cis-12 CLA treatment. The pixel volume for each spot was calculated based on spot intensity and spot area, followed by normalization with the total pixel volume of all the spots revealed in the gel image. Protein spot intensities showing a twofold increase or decrease were considered as differentially expressed. This cut-off was chosen based on previous observations that cis-9,trans-11 CLA treatment overexpress at least by two-fold on some enzymes when compared to trans-10,cis-12 CLA treatment [24]. Differential proteomic analyses using a 2-3-fold cutoff have also been conducted by others [25-27].

\subsection{Identification and functional description of differentially expressed proteins}

The different expression levels of the proteins differentially expressed between the isolates were identified by an automatic NCBInr database search using combined MS and MS/MS data. This approach allowed the identification of 50 proteins, of which 25 correspond to different functional genes (Table 1). All identifications were confirmed by manual interpretation of the tandem mass spectra. When compared to the cis-9,trans-11 CLA treatment and control protein profile, the trans-10,cis-12 CLA treatment presented 14 upregulated proteins which are Patatin-like phospholipase domaincontaining protein 2 (125\%), carnitine palmitoyltransferase $1 \mathrm{~A}$ (150\%), hormone-sensitive lipase (200\%), perilipin (175\%), PPAR $\alpha$ (200\%), UCP1 (150\%), UCP3 (200\%), EP2E protein (125\%), tumor necrosis factor $\alpha$ (TNF- $\alpha)(200 \%)$, MHC class II antigen (150\%), 5'AMP-activated protein (200\%), rearranged T-cell receptor (125\%), calsequestrin-2 (125\%), aspartate aminotransferase (125\%) and two down-regulated proteins which are UCP2 (50\%) and Stearoyl-CoA desaturase (75\%) (Fig. 1 and Table 2).

Fig. 1. Comparison of 2-DE patterns of 3T3-L1 cell lines treated with. (A) placebo; (B) cis-9,trans-11 CLA; (C) trans-10,cis-12 CLA. Fifty-two protein spots were found to vary in a significant way during the treatment.

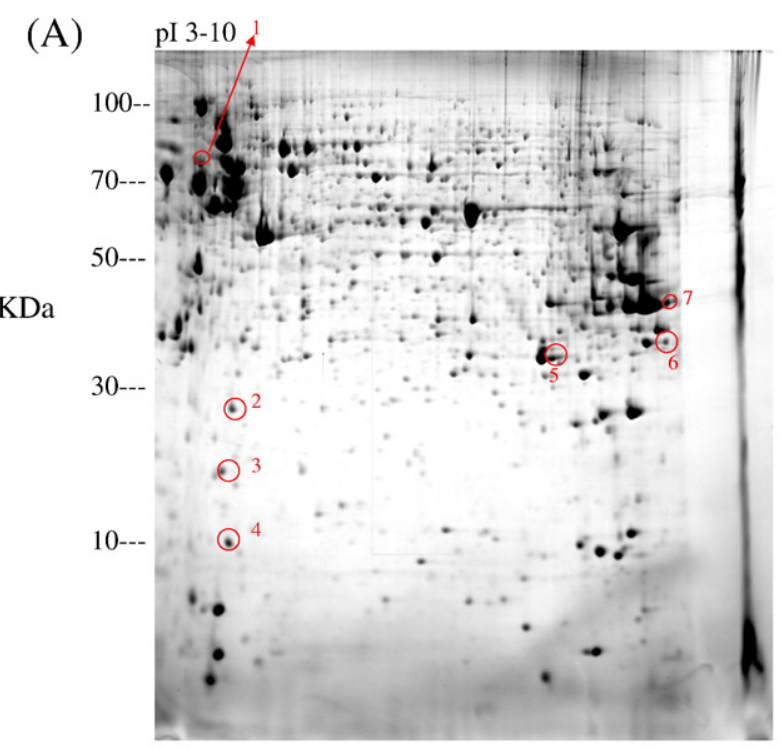

(B) pI 3-10

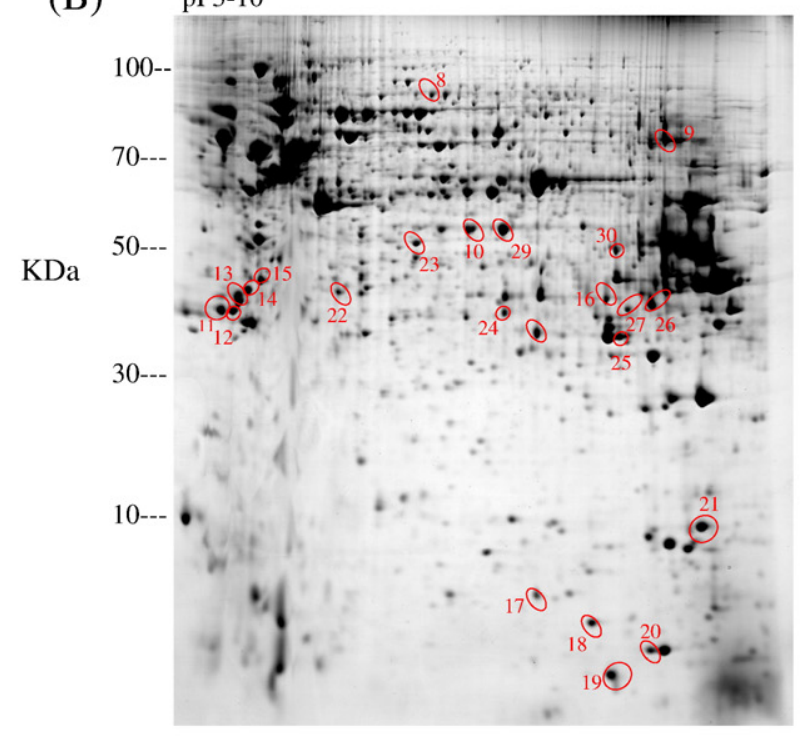

(C)

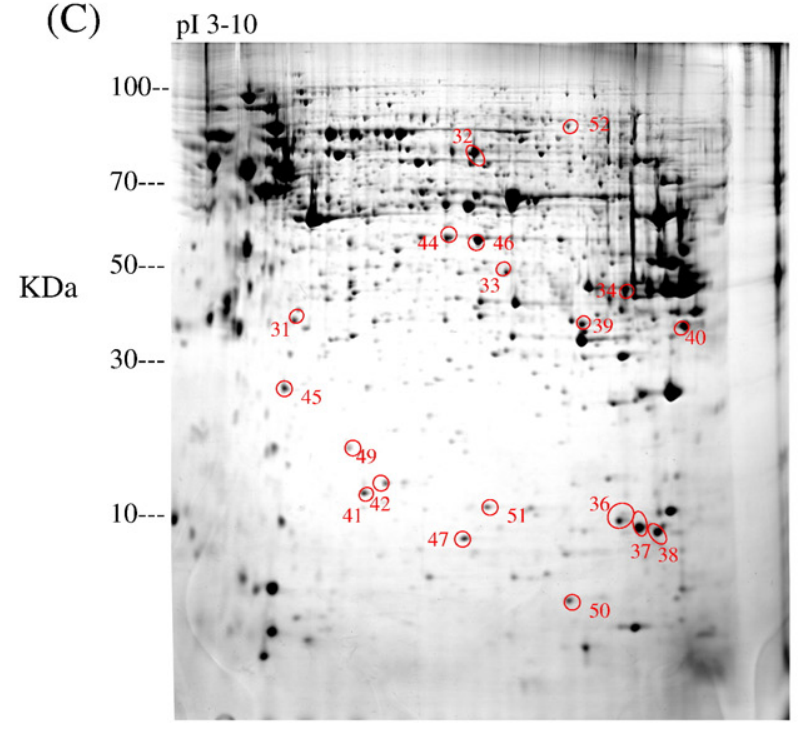


Table 2

Proteins identified by MALDI-TOF MS and their expression variations in different treatment

\begin{tabular}{|c|c|c|c|c|c|c|c|c|c|c|}
\hline Code & Protein name & $\begin{array}{l}\text { Swiss-prot } \\
\text { accession }\end{array}$ & $\begin{array}{l}\text { MW no. } \\
\text { theor. }\end{array}$ & $\begin{array}{l}\text { PI theor. } \\
\text { pep. }\end{array}$ & $\begin{array}{l}\text { Matching pep./ } \\
\text { Identified by } \\
\text { MS/MS }\end{array}$ & Pep. sequence & $\begin{array}{l}\text { Protein } \\
\text { score }\end{array}$ & $\begin{array}{l}\text { Ion } \\
\text { score }\end{array}$ & $\begin{array}{l}\text { Expression in } \\
\text { cis-9,trans-11 } \\
\text { CLA treatment }\end{array}$ & $\begin{array}{l}\text { Expression in } \\
\text { trans-10,cis-12 } \\
\text { CLA treatment }\end{array}$ \\
\hline 33 & $\begin{array}{l}\text { Patatin-like phospholipase } \\
\text { domain-containing protein } 2\end{array}$ & Q8BJ56 & 53657 & 6.02 & $12 / 3$ & $\begin{array}{l}\text { HFSSKDELIQANVC } \\
\text { NIHELRVTNT } \\
\text { MTTLSNMLPV }\end{array}$ & 397 & 346 & & $\uparrow$ \\
\hline 9 & $\begin{array}{l}\text { Carnitine palmitoyltransferase } \\
\text { 1A }\end{array}$ & P97742 & 88251 & 8.67 & $10 / 4$ & $\begin{array}{l}\text { SYHGWMFAEHGKMSR } \\
\text { S ETDTIQHVKDSRH } \\
\text { TDVFQLGYSE } \\
\text { QQQVELFDFEKYPD } \\
\text { VRVPDGIMAAYPVTT }\end{array}$ & 276 & 295 & & $\uparrow$ \\
\hline 32 & Hormone-sensitive lipase & P54310 & 83348 & 6.49 & $17 / 3$ & $\begin{array}{l}\text { VQRDTSLFLRDLR } \\
\text { SVSEAALAQPE }\end{array}$ & 77 & 89 & & $\uparrow$ \\
\hline 46 & Perilipin & Q8CGN5 & 55578 & 6.58 & $3 / 2$ & $\begin{array}{l}\text { NPRGLLGGVVHTVQN } \\
\text { PAQAVSSTKGRAM } \\
\text { SPFSSGSPSRGLFSR }\end{array}$ & 219 & 281 & $\uparrow$ & $\uparrow$ \\
\hline 30 & AMPK gamma2 & Q91WG5 & 62997 & 9.71 & $20 / 4$ & $\begin{array}{l}\text { ESSPNSNPSTSPGGIRFF } \\
\text { FQSPARPPLASPTYHAPLRT } \\
\text { PISGNALYILTHKRILKFL } \\
\text { DGSGTYTKLQ NTQ }\end{array}$ & 189 & 178 & $\uparrow$ & \\
\hline 52 & $\begin{array}{l}\text { PPAR } \alpha \text {-protein interacting } \\
\text { complex } 320 \mathrm{kDa}\end{array}$ & Q8BYH8 & 323860 & 7.61 & $5 / 2$ & TWE LKEDVDLAKI & 214 & 19 & $\uparrow$ & $\uparrow$ \\
\hline 26 & UCP2 & P70406 & 33374 & 9.16 & $14 / 3$ & $\begin{array}{l}\text { RTEGPRSLYN GL } \\
\text { GGGRRYQSTVEAY } \\
\text { KDTLLKANLMTDD } \\
\text { YVWRNIILMSLLHLGAL }\end{array}$ & 87 & 90 & $\downarrow$ & $\downarrow$ \\
\hline 34 & Stearoyl-CoA desaturase & AAR87714 & 41245 & 9.38 & $15 / 4$ & $\begin{array}{l}\text { SAVGVTAGAHRLWS } \\
\text { GILLMCFILPTI } \\
\text { SAAHLYGYRPYDKTIS }\end{array}$ & 141 & 145 & & $\downarrow$ \\
\hline 39 & UCP1 & P12242 & 33248 & 7.99 & $17 / 2$ & $\begin{array}{l}\text { TFPLDTAKVR LQI } \\
\text { ESL STLWKGTTPN } \\
\text { QFYTPKGADH SS }\end{array}$ & 173 & 189 & $\uparrow$ & $\uparrow$ \\
\hline 17 & UCP3 & P56501 & 33911 & 4.38 & $5 / 3$ & $\begin{array}{l}\text { DAYRTIAREEG } \\
\text { FTDNFPCHFVSA }\end{array}$ & 167 & 211 & $\uparrow$ & $\uparrow$ \\
\hline 39 & EP2E protein & Q1RLJ2 & 9527 & 6.56 & $3 / 2$ & $\begin{array}{l}\text { AHTAHLQETG } \\
\text { SVKI HFVGDIPPGI }\end{array}$ & 96 & 78 & & $\uparrow$ \\
\hline 21 & Calsequestrin-2 (fragment) & ACYP2 & 11206 & 9.6 & $4 / 2$ & $\begin{array}{l}\text { VCFRMYTEDE } \\
\text { KNTSKGTVTGQVQ } \\
\text { LLSLNLVHGVF }\end{array}$ & 119 & 134 & $\uparrow$ & \\
\hline 26 & Type X collagen & Q9N178 & 65447 & 9.97 & $5 / 3$ & $\begin{array}{l}\text { PRGHPGPSGP } \\
\text { GDMGPAGLPGPRG } \\
\text { SAWWQKLQIVNEY }\end{array}$ & 81 & 90 & $\uparrow$ & \\
\hline 44 & TNF- $\alpha$ & Q9QXP7 & 32009 & 5.39 & $13 / 4$ & $\begin{array}{l}\text { EDKKACQFKRSFLKNCSG } \\
\text { GQPCILLKMNRIVGFRP } \\
\text { PESASFDLRYYPYYGKL } \\
\text { IQSSITFLCGKTLGT }\end{array}$ & 71 & 68 & & $\uparrow$ \\
\hline 8 & $\begin{array}{l}\text { Mannose-6-phosphate/ } \\
\text { insulin-like growth factor }\end{array}$ & Q95LC9 & 252552 & 5.17 & $19 / 3$ & $\begin{array}{l}\text { LQPLSRVGDA PYTCEGE } \\
\text { GVGLP EYQEEDNSTY } \\
\text { FDSDVGEFRAV }\end{array}$ & 85 & 90 & $\uparrow$ & \\
\hline 41 & MHC class II antigen (fragment) & Q5DLW7 & 10656 & 4.98 & $4 / 3$ & $\begin{array}{l}\text { TPLGRPDADYLNGQK } \\
\text { KRAELDTVCK }\end{array}$ & 75 & 69 & & $\uparrow$ \\
\hline 31 & $\begin{array}{l}\text { 5'-AMP-activated protein kinase } \\
\text { subunit gamma-3 }\end{array}$ & Q9MYP4 & 56790 & 5.07 & $12 / 2$ & $\begin{array}{l}\text { RDILPSDCAASASD } \\
\text { LTALDIFVDRRVSALPV }\end{array}$ & 69 & 72 & & $\uparrow$ \\
\hline 36 & $\begin{array}{l}\text { rearranged T-cell receptor } \\
\text { delta-chain }\end{array}$ & I46626 & 16950 & 8.93 & $4 / 2$ & $\begin{array}{l}\text { AQKVTQDQPVVS } \\
\text { YFINFQKAQKSLS }\end{array}$ & 66 & 61 & & $\uparrow$ \\
\hline 20 & ATP synthase e chain & Q9MYT8 & 8232 & 9.71 & $3 / 2$ & $\begin{array}{l}\text { ALFLGVAYGAKRY } \\
\text { RRIAAEEKKKQ }\end{array}$ & 69 & 72 & $\uparrow$ & \\
\hline 21 & $\begin{array}{l}\text { Phosphorylase kinase gamma } \\
\text { subunit }\end{array}$ & 077789 & 13873 & 9.75 & $5 / 2$ & $\begin{array}{l}\text { CSAEEALAHPFFQQ } \\
\text { FENTPKAVLL } \\
\text { FDGEFAADVLVEF }\end{array}$ & 66 & 61 & $\uparrow$ & \\
\hline 38 & Calsequestrin-2 & 18934 & 18990 & 4.51 & $9 / 3$ & $\begin{array}{l}\text { YYKAFEEAAEHF } \\
\text { |TFDKGVAKKLSLKM } \\
\text { TISGTGALRIGANF }\end{array}$ & 55 & 65 & & $\uparrow$ \\
\hline 40 & Aspartate aminotransferase & P00506 & 47436 & 9.01 & $14 / 3$ & $\begin{array}{l}\text { FSRDVFLPKPSWG } \\
\text { PRPEQWKEMATLV }\end{array}$ & 53 & 60 & & $\uparrow$ \\
\hline 18 & $\begin{array}{l}\text { Cyclin dependant kinase } \\
\text { inhibitor }\end{array}$ & Q8SPK2 & 16298 & 5.65 & $13 / 2$ & $\begin{array}{l}\text { RALLEAGALANAPN } \\
\text { AWGRLPVDLAEER } \\
\text { IKTLNILTARKNSC }\end{array}$ & 50 & 61 & $\uparrow$ & \\
\hline 19 & interleukin-4 & S28187 & 14892 & 9.09 & $5 / 3$ & $\begin{array}{l}\text { DVFAAPENTTEK } \\
\text { |CMKSLLSGLDRNLSSM }\end{array}$ & 48 & 54 & $\uparrow$ & \\
\hline
\end{tabular}



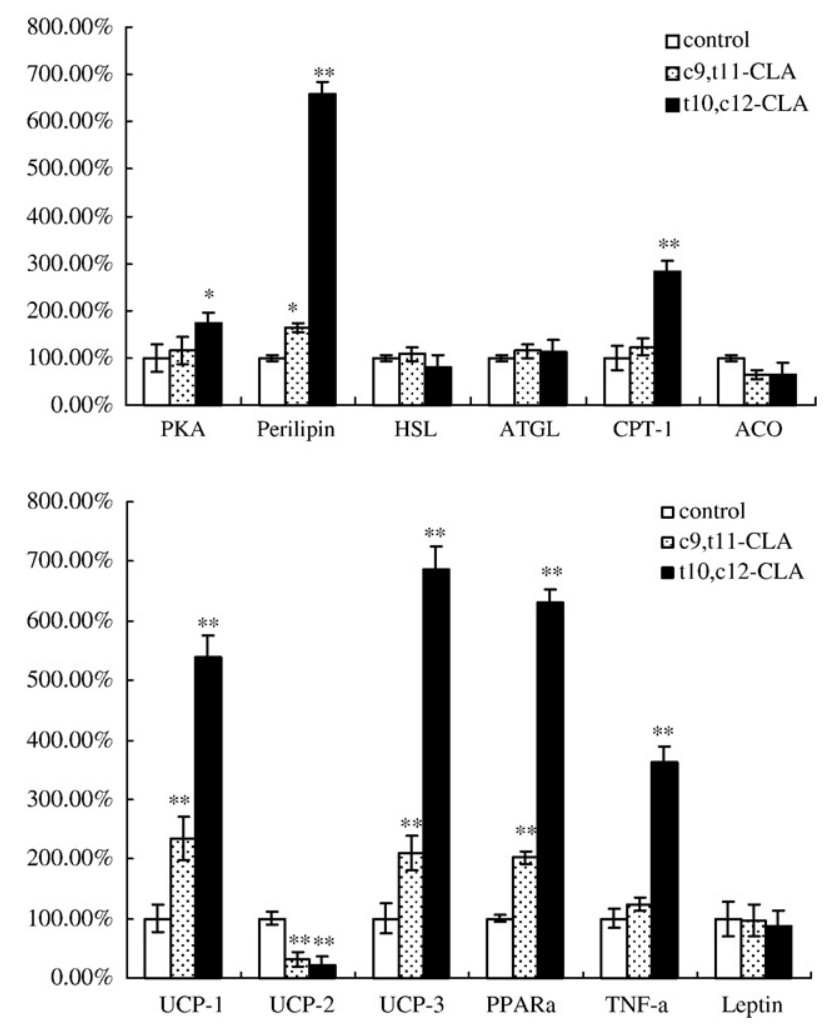

Fig. 2. Effects of CLA isomers on mRNA abundance of key genes in 3T3-L1. Values are least squares means \pm S.E.M., $n=6$. Values are expressed relative to the control. ${ }^{*} P<.05$; ${ }^{* *} P<.01$.

\subsection{RNA isolation and $q R T-P C R$}

3.3.1. Effects of trans-10, cis-12 CLA on the mRNA levels of UCP-1,UCP3, PPAR $\alpha$, perilipin, CPT-1, TNF- $\alpha$ and PKA

The housekeeping gene $\beta$-actin was treated as an internal control. Values are expressed relative to the vehicle control (Fig. 2). The treatment of cis-9,trans-11 CLA led to a double increase in the expressions of the UCP1, UCP3 mRNA and PPAR $\alpha$ mRNA $(P<.01)$, and a up-regulation in the expression of perilipin mRNA by $64 \%(P<.05)$ as compared with the control group. The mRNA level of UCP2 was markedly inhibited by cis-9,trans-11 CLA $(P<.01$, dropped to $31.3 \%)$.

It is valuable to note that trans-10,cis-12 CLA showed to modulate the genes related to lipid metabolisms in the adipocytes. Treatment of trans-10, cis-12 CLA led a 539\%, and 686\%,630\% and 657\% increases in the expression of UCP-1,UCP3, PPAR $\alpha$ and perilipin at mRNA level respectively as compared with the control group. Meanwhile, trans10,cis-12 CLA markedly decreased the mRNA level of UCP2, which is about the one fourth of the control level. Treatment of trans-10,cis-12 CLA also induced a $282 \%$ increase of CPT-1 mRNA $(P<.01)$, which was much higher than those of cis-9,trans-11 CLA. Treatment of trans-10, cis-12 CLA up-regulated the level of TNF- $\alpha$ mRNA by $362 \%(P<.01)$, treble of cis-9,trans-11 CLA treatment. Moreover, trans-10,cis-12 CLA enhanced significantly the expression of PKA by $73.6 \%(P<.05)$. Compared with control, trans-10,cis-12 isomer had no effect on the expression of HSL, ATGL, ACO and leptin.

\section{Discussion}

\subsection{Effect of CLA isomers on energy expenditure in 3T3-L1}

UCPs are mitochondrial inner-membrane transporters responsible for heat generation through forming a pathway for proton flux from cytosol to mitochondrial matrix [28]. They are important regulators of thermogenesis, although the role of UCP2 and UCP3 in thermogenesis is still controversial [29]. Metges et al. reported that cis-9,trans-11 CLA increased lipid accumulation and UCP1 mRNA expression in primary adipocytes, whereas trans-10,cis-12 CLA increased lipolysis and inhibited UCP1 mRNA expression [18]. Wang et al. concluded that UCP2 mRNA expression was higher by both cis-9,trans-11 CLA and trans-10,cis-12 CLA treatments [30]. However, our results are different from the previous studies. In the expression of UCP1,our study results are contrasted with the in vivo effects of the mixed CLA as previous report [7]. The up-regulation of UCP1 gene expression by trans-10,cis-12 isomer in our study was in agreement with the study reported by LaRosa et al. [31]. The CLA isomers increased the express of UCP3, but reduced the mRNA levels of UCP2. The protein expression of UCP1 and UCP3 proteins had not changed, but the UCP2 protein was down-regulated by trans-10,cis-12 CLA treatment. UCP1 is known to play a crucial role in increasing energy expenditure in brown adipose tissue, the enhancement of thermogenesis is due to up-regulation of UCP1 [32]. UCP2 is a mitochondrial inner-membrane protein that mediates proton leakage by uncoupling adenosine triphosphate synthesis [33] Down-regulation of UCP2 protein expression may compromise cellular adenosine triphosphate levels and increase metabolic efficiency and, thus increasing energy expenditure. All in all, we conclude that both isomers increased energy expenditure in adipocytes and trans-10,cis-12 CLA exerted a stronger thermogenic effect than cis-9,trans-11 CLA.

\subsection{Effect of CLA isomers on fatty acid oxidation in 3T3-L1}

PPAR $\alpha$ gene is predominantly expressed in tissues with high mitochondrial and peroxisomal $\beta$-oxidation activities of fatty acids, such as adipose tissue, liver and muscle [34]. It is a known that the transcription factor for ACO (peroxisomal $\beta$-oxidation), CPT-1 (mitochondrial $\beta$-oxidation) and other genes involved in the cellular fatty acid utilization pathway $[2,35,36]$. Increase in PPAR $\alpha$ mediates the up-regulation of ACO and CPT- 1 , thus the degree of PPAR $\alpha$ activation may be correlated to the degree of fatty acid $\beta$-degradation [37]. It has been already reported that CLA act as a legend of PPAR $\alpha$ [24]. We found that both isomers increased mRNA and protein levels of PPAR $\alpha$, though the extent was not so much in cis-9,trans-11 CLA treatment ( $200 \%$ vs $630 \%$ for mRNA and $120 \%$ vs $200 \%$ for protein).

Eight days treatment of the trans-10,cis-12 CLA, but not the cis-9, trans-11 CLA, also significantly up-regulated the gene and protein expression of CPT-1 protein. Higher CPT- 1 could be explained by the increase in PPAR $\alpha$; however, the results in current study suggested that both CLA isomers tended to inhibit ACO expression. As mitochondrial $\beta$-oxidation is approximately twice as efficient as peroxisomal $\beta$-oxidation [34], we still believed that fatty acid oxidation was promoted by trans-10,cis-12 CLA in this experiment.

\subsection{Effect of CLA isomers on apoptosis in 3T3-L1}

Previous studies conducted by Evans et al. [21] and Hargrave et al. [22] indicate that trans-10,cis-12 CLA is the effective isomer to promotes apoptotic cell death in fat cells. The body fat-lowering effect of CLA may be partly explained by the induction of apoptosis. Tumor necrosis factor alpha (TNF- $\alpha$ is a cytokine known to activate lipolysis and apoptosis in adipocytes [23] CLA supplementation could up-regulate the level of TNF- $\alpha[12,38]$. We got the similar results, showing the increase of TNF- $\alpha$ induced by trans-10, cis-12 CLA. The apoptotic cell death induced by trans-10,cis-12 CLA may be associated with the enhancement of TNF$\alpha$. As TNF- $\alpha$ is the mediator with both the pro- and anti-apoptotic functions in adipocytes [23]. The increase of TNF- $\alpha$ expression may not directly lead to apoptosis in the adipocytes. Other proteins involved in apoptosis should be investigated before the conclusion can be drawn. 
Theoretically, up-regulation of leptin production and inhibition of perilipin were correlated with increase in TNF- $\alpha$ [25], but a paradoxical effect was observed in this study. Lepin is a lipostatic hormone secreted by mature adipocytes. It is important in the regulation of body weight and energy metabolism, reducing body weight by reduced food intake and accelerated energy expenditure [27]. It is known to up-regulate enzymes of fatty acid oxidation and their transcription factors [39] and induce apoptosis [40]. However, the suppression of leptin mRNA expression by trans-10,cis-12 CLA was reported by several studies $[19,30,41]$. We got similar results in this experiment, though the change was not significantly different. The reduction of leptin mRNA level was not consistent with increase in TNF- $\alpha$, because gene expression of leptin was influenced by other factors. Reduced leptin expression indicates the transformation of adipocytes from cells that store triglycerides to fatty acid-oxidizing cells [39]. Therefore, we conclude that down-regulation of leptin by trans-10,cis-12 CLA treatment is associated with its lipid-lowering effect.

\subsection{Effect of CLA isomers on lipolysis in 3T3-L1}

Perilipin surrounds lipid droplets, serving as a functional barrier to shield stored triglyceride (TG) against the basal lipolytic actions of cellular lipases [42]. TG storage is protected by unphosphorylated perilipin. PKA-mediated phosphorylation of HSL and perilipin promotes perilipin movement from the surface of lipid droplets to the cytosol, leading to increased lipolysis $[43,44]$. Chronic treatment $(\geqq 48 \mathrm{~h}$ ) of trans-10,cis-12 CLA is reported to down-regulate the expression of perilipin [45]., but our data showed that both isomers, especially trans-10,cis-12 CLA up-regulated the expression of perilipin at protein and mRNA levels. This may be related to the different doses and experimental conditions used.

Our data also showed that the levels of PKA protein and mRNA level was significantly enhanced by trans-10,cis-12 CLA. Up-regulation of PKA expression is related to enhanced phosphorylation of perilipin and HSL, thus stimulating lipolysis. For trans-10,cis-12 CLA, increase in PKA expression attenuated the effect of increased perilipin expression. Moreover, results from this experiment suggested that both isomers did not present significant influence on gene expression of HSL, which is the enzyme once known as the exclusive one to hydrolyze triglycerides. The decline in the gene expression of HSL was consistent with other studies $[31,45]$. This change may be explained by lower leptin level, because leptin because leptin regulates lipolysis by controlling the level of HSL [46]. However, basal lipolysis may be induced by other mechanisms other than the classic cAMP-driven, PKA-mediated phosphorylation of HSL and perilipin [45]. Adipose TG lipase (ATGL) was of interest in this study. It was recently described to predominantly perform the initial step in TG hydrolysis [47]. But data indicate that no significant influence in gene expression of ATGL was obtained in either isomer treatment. Eventually, judging by the expression of related gene and protein, we concluded that the lipolysis effect was not affected by both trans-10,cis-12 and cis-9,trans-11 CLA.

In conclusion, after 8 days of high dose treatment, trans-10,cis-12 CLA exhibited greater influence on lipid metabolism than cis-9,trans11 CLA. cis-9,trans-11 CLA may induce an increase in energy expenditure, but it had little influence on apoptosis, fatty acid oxidation and lipolysis in adipocytes. trans-10,cis-12 CLA stimulated adipocyte energy expenditure, apoptosis and fatty acid oxidation, but its effect on lipolysis was not obvious.

\section{References}

[1] Blankson H, Stakkestad JA, Fagertun H, Thom E, Wadstein J, Gudmundsen O. Conjugated linoleic acid reduces body fat mass in overweight and obese humans. J Nutr 2000;130:2943-8.
[2] Mascaro C, Acosta E, Ortiz JA, Marrero PF, Hegardt FG, Haro D. Control of human muscle-type carnitine palmitoyltransferase I gene transcription by peroxisome proliferator-activated receptor. J Biol Chem 1998;273:8560-3.

[3] Pariza MW, Park Y, Cook ME. The biologically active isomers of conjugated linoleic acid. Prog Lipid Res 2001;40:283-98.

[4] Whigham LD, Cook ME, Atkinson RL. Conjugated linoleic acid: implications for human health. Pharmacol Res 2000;42:503-10.

[5] Park Y, Albright KJ, Liu W, Storkson JM, Cook ME, Pariza MW. Effect of conjugated linoleic acid on body composition in mice. Lipids 1997;32:853-8.

[6] House RL, Cassady JP, Eisen EJ, McIntosh MK, Odle J. Conjugated linoleic acid evokes de-lipidation through the regulation of genes controlling lipid metabolism in adipose and liver tissue. Obes Rev 2005;6:247-58.

[7] Takahashi Y, Kushiro M, Shinohara K, Ide T. Dietary conjugated linoleic acid reduces body fat mass and affects gene expression of proteins regulating energy metabolism in mice. Comp Biochem Physiol B Biochem Mol Biol 2002;133: 395-404.

[8] Yamasaki M, Mansho K, Mishima H, Kasai M, Sugano M, Tachibana H, et al. Dietary effect of conjugated linoleic acid on lipid levels in white adipose tissue of SpragueDawley rats. Biosci Biotechnol Biochem 1999;63:1104-6.

[9] Mougios V, Matsakas A, Petridou A, Ring S, Sagredos A, Melissopoulou A, et al. Effect of supplementation with conjugated linoleic acid on human serum lipids and body fat. J Nutr Biochem 2001;12:585-94.

[10] Zambell KL, Keim NL, Van Loan MD, Gale B, Benito P, Kelley DS, et al. Conjugated linoleic acid supplementation in humans: effects on body composition and energy expenditure. Lipids 2000;35:777-82.

[11] Park Y, Storkson J, Albright KJ, Liu W, Pariza MW. Evidence that the trans-10, cis12 isomer of conjugated linoleic acid induces body composition changes in mice. Lipids 1999;34:235-41.

[12] Brown JM, Boysen MS, Chung S, Fabiyi O, Morrison RF, Mandrup S, et al. Conjugated linoleic acid induces human adipocyte delipidation: autocrine/ paracrine regulation of MEK/ERK signaling by adipocytokines. J Biol Chem 2004;279:26735-47.

[13] Kang K, Liu W, Albright KJ, Park Y, Pariza MW. trans-10,cis-12 CLA inhibits differentiation of 3T3-L1 adipocytes and decreases PPAR gamma expression. Biochem Biophys Res Commun 2003;303:795-9.

[14] Wahli W, Braissant O, Desvergne B. Peroxisome proliferator activated receptors: transcriptional regulators of adipogenesis, lipid metabolism and more. Chem Biol 1995;2:261-6.

[15] Evans M, Park Y, Pariza M, Curtis L, Kuebler B, McIntosh M. Conjugated linoleic acid reduces triglyceride content while differentially affecting peroxisome proliferator activated receptor 2 and aP2 expression in 3T3-L1 preadipocytes. Lipids 2001;36:1223-32.

[16] Granlund L, Juvet LK, Pedersen JI, Nebb HI. Trans10, cis12-conjugated linoleic acid prevents triacylglycerol accumulation in adipocytes by acting as a PPAR $\alpha$ modulator. J Lipid Res 2003;44:1441-52.

[17] He ML, Hnin TM, Kuwayama H, Mir PS, Okine EK, Hidari H. Effect of conjugated linoleic acid type, treatment period, and dosage on differentiation of 3T3 cells. Lipids 2006;41:937-49.

[18] Metges CC, Lehmann L, Boeuf S, Petzke KJ, Müller A, Rickert R, et al. cis-9,trans-11 and trans-10,cis-12 CLA affect lipid metabolism differently in primary white and brown adipocytes of Djungarian hamsters. Lipids 2003;38:1133-42.

[19] Kang K, Pariza MW. trans-10,cis-12-Conjugated linoleic acid reduces leptin secretion from 3T3-L1 adipocytes. Biochem Biophys Res Commun 2001;287: 377-82.

[20] Frost SC, Lane MD. Evidence for the involvement of vicinal sulfhydryl groups in insulin-activated hexose transport by 3T3-L1 adipocytes. J Biol Chem 1985;260: 2646-52.

[21] Evans M, Geigerman C, Cook J, Curtis L, Kuebler B, McIntosh M. Conjugated linoleic acid suppresses triglyceride accumulation and induces apoptosis in 3T3-L1 preadipocytes. Lipids 2000;35:899-910.

[22] Hargrave KM, Changlong LI, Meyer BJ, Kachman SD, Hartzell DL, Della-Fera MA et al. Adipose depletion and apoptosis induced by trans-10,cis-12 conjugated linoleic acid in mice. Obes Rev 2002;10:1284-90.

[23] Zhang HH, Kumar S, Barnett AH, Eggo MC. Dexamethasone inhibits tumor necrosis factor- $\alpha$-induced apoptosis and interleukin- $1 \beta$ release in human subcutaneous adipocytes and preadipocytes. J Clin Endocrinol Metab 2001;86: 2817-25.

[24] Moya-Camarena SY, Vandem Heuvel JP, Blanchard SG, Leesnitzer LA, Belury MA. Conjugated linoleic acid is a potent naturally occurring ligand and activator of PPAR $\alpha$. J Lipid Res 1999;40:1426-33.

[25] Hotamisligil GS, Murry D, Choy LN, Spiegelman BM. Tumor necrosis factor alpha inhibits signaling from the insulin receptor. Proc Natl Acad Sci U S A 1994;91: 4854-8.

[26] Souza SC, de Vargas LM, Yamamoto MT, Lien P, Franciosa MD, Moss LG, et al. Overexpression of perilipin A and B blocks the ability of tumor necrosis factor alpha to increase lipolysis in 3T3-L1 adipocytes. J Biol Chem 1998;273:24665-9.

[27] van Dijk G. The role of leptin in the regulation of energy balance and adiposity. J Neuroendocrinol 2001;13:913-21.

[28] Klingenberg M, Huang SG. Structure and function of the uncoupling protein from brown adipose tissue. Biochim Biophys Acta 1999;1415:271-96.

[29] Krauss S, Zhang CY, Lowell BB. The mitochondrial uncoupling-protein homologues. Nat Rev Mol Cell Biol 2005;6:248-61.

[30] Wang YM, Nagao K, Inoue N, Ujino Y, Shimada Y, Nagao T, et al. Isomer-specific anti-obese and hypolipidemic properties of conjugated linoleic acid in obese OLETF rats. Biosci Biotechnol Biochem 2006;70:355-62. 
[31] LaRosa PC, Miner J, Xia Y, Zhou Y, Kachman S, Fromm ME. Trans-10, cis-12 conjugated linoleic acid causes inflammation and delipidation of white adipose tissue in mice: a microarray and histological analysis. Physiol Genomics 2006;27: 282-94.

[32] Adams SH. Uncoupling protein homologs: emerging views of physiological function. J Nutr 2000;130:711-4.

[33] Nagy TR, Bayblock ML, Garvey WT. Role of UCP2 and UCP3 in nutrition and obesity. Nutrition 2004;20:139-44.

[34] Guan Y, Breyer MD. Peroxisome proliferator-activated receptors (PPARs): novel therapeutic targets in renal disease. Kidney Int 2001;60:14-30.

[35] Djouadi F, Brandt JM, Weinheimer CJ, Leone TC, Gonzalez FJ, Kelly DP. The role of the peroxisome proliferator-activated receptor alpha (PPAR alpha) in the control of cardiac lipid metabolism. Prostaglandins Leukot Essent Fatty Acids 1999;60: 339-43.

[36] Kersten S, Desvergne B, Wahli W. Roles of PPARs in health and disease. Nature 2000;405:421-4.

[37] Schoonjans K, Staels B, Auwerx J. Role of the peroxisome proliferator activated receptor (PPAR) in mediating the effects of fibrates and fatty acids on gene expression. J Lipid Res 1996;37:907-25.

[38] Tsuboyama-Kasaoka N, Takahashi M, Tanemura K, Kim HJ, Tange T, Okuyama H, et al. Conjugated linoleic acid supplementation reduces adipose tissue by apoptosis and develops lipodystrophy in mice. Diabetes 2000;49:1534-42.

[39] Zhou YT, Wang ZW, Higa M, Newgard CB, Unger RH. Reversing adipocyte differentiation: implications for treatment of obesity. Proc Natl Acad Sci U S A 1999;96:2391-5.
[40] Qian H, Azain MJ, Compton MM, Hartzell DL, Hausman GJ, Baile CA. Brain administration of leptin causes deletion of adipocytes by apoptosis. Endocrinology 1998;139:791-4.

[41] Perez-Matute P, Marti A, Martinez JA, Fernandez-Otero MP, Stanhope KL, Havel PJ, et al. Conjugated linoleic acid inhibits glucose metabolism, leptin and adiponectin secretion in primary cultured rat adipocytes. Mol Cell Endocrinol 2007;268:50-8.

[42] Brasaemle DL, Rubin B, Harten IA, Gruia-Gray J, Kimmel AR, Londos C. Perilipin A increases triacylglycerol storage by decreasing the rate of triacylglycerol hydrolysis. J Biol Chem 2000;275:38486-93.

[43] Clifford G, Landos C, Kraemer F, Vernon R. Translocation of hormone-sensitive lipase and perilipin upon lipolytic stimulation of rat adipocytes. J Biol Chem 2000;275:5011-5.

[44] Sztalryd C, Xu G, Dorward H, Tansey JT, Contreras, Kimmel AR, et al. Perilipin A is essential for the translocation of hormone sensitive lipase during lipolytic activation. J Cell Biol 2003;161:1093-103.

[45] Chung S, Brown JM, Sandberg MB, McIntosh M. Trans-10,cis-12 CLA increases adipocyte lipolysis and alters lipid droplet-associated proteins: role of mTOR and ERK signaling. J Lipid Res 2005;46:885-95.

[46] Sarmiento U, Benson B, Kaufman S, Ross L, Qi M, Scully S, et al. Morphologic and molecular changes induced by recombinant human leptin in the white and brown adipose tissues of C57BL/ 6 mice. Lab Invest 1997;77:243-56.

[47] Zimmerman R, Strauss JG, Haemmerle G, Schoiswohl G, Birner-Gruenberger R, Riederer $\mathrm{M}$, et al. Fat mobilization in adipose tissue is promoted by adipose triglyceride lipase. Science 2004;306:1383-6. 